\title{
The Geology and Emplacement History of the Pigeon Kimberlite, EKATI Diamond Mine, Northwest Territories, Canada
}

\author{
B.B. Crawford ${ }^{1}$, C.M. Hetman ${ }^{2}$, T.N. Nowicki ${ }^{2}$, M.C. Baumgartner ${ }^{2}$ \\ ${ }^{1}$ BHP Billiton Diamonds Inc., Kelowna, Canada; ${ }^{2}$ Mineral Services Canada Inc., Vancouver, Canada
}

\section{Introduction}

The Pigeon kimberlite is located approximately $6 \mathrm{~km}$ northwest of the Koala cluster of the EKATI Diamond Mine, and is presently one of ten kimberlite pipes in the EKATI resource development plan (Figure 1). The pipe was first identified in a 1991 airborne geophysical survey as a weak conductivity anomaly coincident with a strong magnetic low response and was confirmed as kimberlite by core drilling in 1993 . The emplacement age is inferred from sedimentary xenoliths present within the pipe and falls within 45-75 Ma range.

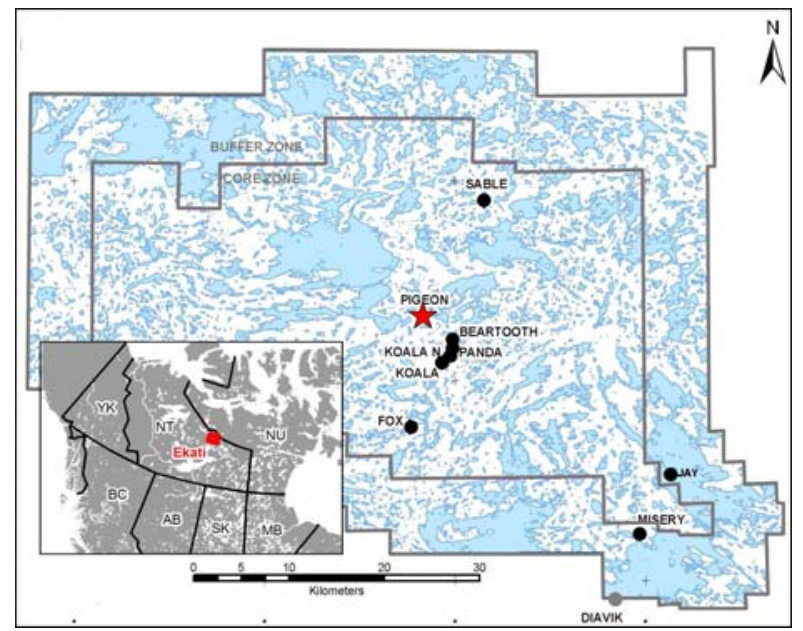

Figure 1: Map of the EKATI property showing the location of Pigeon (red star) and other kimberlite pipes presently included in the EKATI resource development plan (black dots). Blue indicates water bodies.

Evaluation work conducted to date on the body has included airborne and ground geophysical surveys, detailed logging of drill core and reverse circulation drill chips, petrography, mineral abundance and composition studies, and diamond analysis. The geological model and emplacement history of the Pigeon kimberlite presented in this contribution has been developed from these investigations.

\section{Geologic Setting}

The Pigeon kimberlite occurs along a regional lithological contact between syn-tectonic granitoid rocks and Yellowknife Supergroup metasedimentary rocks that run southeast-northwest orientation (Kjarsgaard, 2001). Two parallel diabase dykes intrude in a north-south direction adjacent to the Pigeon pipe.
The dykes are approximately $150 \mathrm{~m}$ apart, crosscutting both the granitoid body and the metasediments; the eastern-most dyke is inferred to intersect the pipe (Figure 2). The pipe is presently overlain by locally thick, up to $30 \mathrm{~m}$, rolling ground moraine composed of boulders, gravel, and lesser sand and silt.

\section{Kimberlite Geology}

An undetermined amount of erosion of the pipe has occurred following emplacement and the present surface expression of the body is estimated as 3.5 ha. The morphology of the pipe is similar to most other EKATI kimberlites in that it is steep-sided diatreme that tapers with increasing depth (Figure 2). The pipe is infilled with two main rock types: resedimented volcaniclastic kimberlite (RVK) and texturally complex magmatic / volcaniclastic kimberlite (MK/VK). Subordinate rocks types include primary pyroclastic kimberlite (PVK) and a late stage intrusive coherent kimberlite (CK). In addition to the main kimberlitic infill, granitic blocks as large as $30 \mathrm{~m}$ are concentrated in a distinct zone within the body.

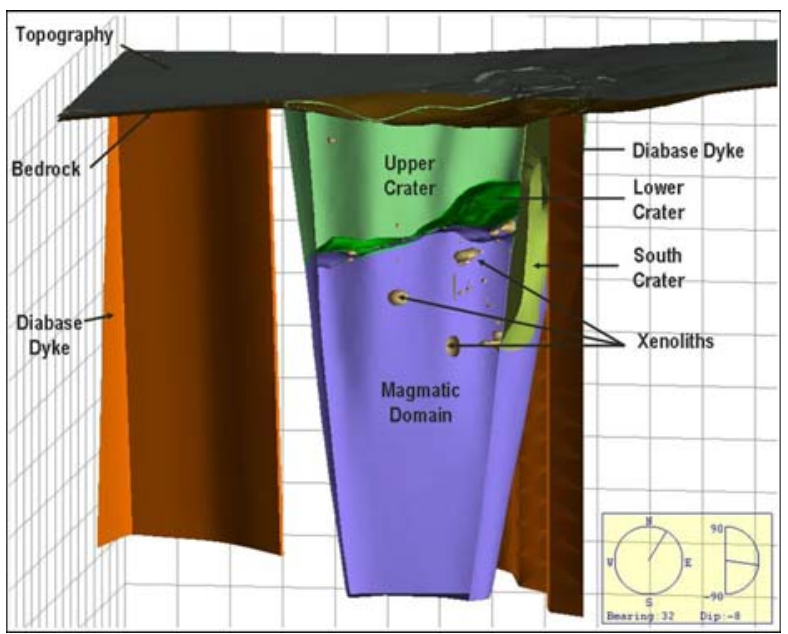

Figure 2: Isometric cut-away view of the 3D Pigeon geology model.

The Pigeon pipe has been grouped into four geological domains that are characterised by contrasting macroscopic and petrographic features, mantle mineral assemblages and grade. The four main domains include the Upper Crater (UC), Lower Crater (LC), Magmatic (MK) and South Crater (SC) domains (Figure 2). 


\section{Upper Crater (UC) Domain}

The UC domain is a thick (up to $200 \mathrm{~m}$ ) sequence of massive, poorly sorted, dark brownish grey to black, muddy, olivine-rich, resedimented volcaniclastic kimberlite (ORVK), similar to that observed in other EKATI kimberlites (Nowicki et al., 2004). Diffuse beds are defined by changes in the proportion of olivine and lithic clasts. Total olivine content ranges from 15 to $25 \%$. These are typically fine- to mediumgrained, but occasional coarser-grained varieties are also present. The distinguishing feature of the UC ORVK is the mud-rich nature of this rock and conspicuous rounded crustal lithic clasts that range from 1 to $4 \mathrm{~cm}$ in diameter. The main lithic population is characterised by mudstones that include black, grey, green-grey and pale brown-orange varieties. Rounded pebbles of quartzite, small relatively fresh granitic xenoliths, and carbonised wood fragments are also present in minor amounts.

In thin section the RVK is characterised by abundant single crystals of olivine and less common juvenile clasts set within a variable interclast matrix dominated by mud and serpentine. The olivine crystals are commonly altered and few fresh remnants are present. Many of the single, free olivines are broken. Packing density varies from matrix to less common clast supported zones. Irregular plastically deformed mudstone clasts are common as well as common fresh granitoid xenoliths and xenocrysts. Juvenile clasts display variable morphology and mineralogy, and cognate lithic fragments of RVK are present

\section{Lower Crater (LC) Domain}

The LC domain occurs between the RVK of the UC domain and the magmatic rocks of the MK domain. It is comprised of a texturally complex and typically highly altered VK material that is distinctly different from the overlying lithic-ORVK due to the absence of mud within the interclast matrix. This domain varies in thickness from approximately $25 \mathrm{~m}$ to $50 \mathrm{~m}$. Macroscopically, it contains between 30 and 60\% pervasively altered, medium- to coarse-grained olivine set in a very fine-grained greyish green matrix that appears to be dominated by serpentine. It is characterised by the presence of variable concentrations of juvenile clasts, including common cored varieties. This domain is characterised by a high proportion of variably altered granitoid country rock xenoliths and minor amounts of small $(<2 \mathrm{~cm})$ mud xenoliths.

Petrographic analysis of this rock type reveals that it is characterised by conspicuous juvenile clasts and less common single olivines set within a highly altered interclast matrix composed of serpentine and rare mud. The majority of the olivines are extensively pseudomorphed by serpentine, talc and carbonate with rare fresh remnants preserved. The proportion of olivine is high and visually estimated as $55 \%$. Juvenile clasts are typically equant, sub-rounded and subirregular in shape. The majority of the juvenile clasts are cored with less common uncored varieties present. Rims are typically ultra-thin to thin and vesicles are not present. Clast margins are well defined and the olivine grain size is similar to the host. A number of juvenile clasts types are present. The groundmass within the selvages contains probable monticellite, spinel and perovskite and is similar in many respects to that of the MK Domain. Country rock xenoliths include fresh granitoid and less common dark brown clasts of mudstone.

\section{Magmatic (MK) Domain}

Located below the LC is a unit dominated by magmatic kimberlite that is texturally variable and includes diffuse zones characterized by volcaniclastic features. Macroscopically the magmatic / volcaniclastic rocks are described as massive and comprise mediumgrained olivine macrocrysts and phenocrysts set in a dark, fine-grained crystalline matrix. Highly altered granitic xenoliths are present and can be locally abundant. Dark brown, mudstone / shale xenoliths are rare to absent.

Although macroscopically this unit appears to be characterised by a coherent texture, in thin section it locally displays subtle volcaniclastic features. The kimberlite is moderately altered and composed of abundant olivine macrocrysts set within an inhomogeneous groundmass. A few of the sections are magmaclastic, however the irregular morphology of a number of these magmaclasts suggest that this texture may have been at least partially developed by a secondary alteration processes. The majority of the olivine macrocrysts are partially fresh with secondary serpentine or carbonate replacing portions of most of the crystals. Olivine phenocrysts are extensively altered and margins of these crystals are difficult to discern. The groundmass contains carbonate, perovskite, probable monticellite and spinel, with a few scattered phlogopite crystals. The thin sections characterised by magmaclastic textures contain carbonate and spinel within the interclast matrix. Although in areas this unit is characterised by a uniform crystalline groundmass, the distribution and morphology of the olivine macrocrysts is suggestive of a volcaniclastic origin.

\section{South Crater (SC) Domain}

The SC domain is located along the southernmost portion of the pipe, directly adjacent to the eastern diabase dyke. Although this domain has not been well constrained, drilling to date indicates it is volumetrically insignificant. This unit is pale brown in colour and characterised by conspicuous diabase xenoliths throughout. Total olivine abundance is visually estimated as 10 to $40 \%$ and is dominated by olivine phenocrysts. Many of the olivines are partially pseudomorphed by serpentine or carbonate with 
common fresh remnants present. The olivines are set within a groundmass characterised by abundant opaque oxides and white carbonate. There are a number of spectacular autoliths of resedimented volcaniclastic kimberlite present throughout the unit. The SC domain displays a generally massive texture with diffuse concentrations of olivine macrocrysts.

Microscopic investigation confirms that this is a coherent (magmatic) rock typically characterised by a coarse-grained, well crystallized groundmass. The samples examined display a wide range of groundmass development and alteration. The unit is characterised by a very low abundance of olivine macrocrysts and these are visually estimated as less than 5\%. The groundmass is comprised of abundant carbonate, coarse-grained spinel, monticellite and phlogopite. Most of the carbonate crystals are typical lath-shaped grains with angled terminations. However, other carbonate laths are characterised by flat terminations and may represent secondary carbonate after melilite. Many of the groundmass spinel crystals are characterised by atoll structures.

\section{Mineral Chemistry Analysis}

Quantitative (Mantle Mapper $^{\mathrm{TM}}$ ) indicator mineral abundance and composition data are available for the Upper Crater and Magmatic domains at Pigeon. The indicator mineral suite is strongly dominated by peridotitic garnet with lesser amounts of eclogitic garnet and Cr-diopside, and minor chromite. Ilmenite is rare to absent and only trace amounts of megacrystic garnet were recovered. The garnets include significant proportions of G10 as well as diamond associated Group 1 eclogitic varieties, suggesting that both peridotitic and eclogitic diamond sources have been sampled. The indicator mineral composition ranges for the two domains sampled are broadly similar. However, subtle but distinct differences in the proportions of specific compositional varieties of garnet are evident, indicating that these two domains contain slightly different mantle samples.

\section{Emplacement of the Pigeon Kimberlite}

The development of the geological features present within the Pigeon kimberlite can be summarized in 6 steps. 1) Initial highly explosive eruption/s excavated the diatreme and crater through the granitoid basement and upper muddy sediments depositing a mixture of country rock and juvenile material outside the pipe. 2) Continued explosive volcanic activity ejects and deposits a mixture of additional juvenile material significant quantities of mud, derived by slumping of unstable crater rims into the active vent. 3) Eruption intensity wanes and the open diatreme is partially infilled with magmatic to volcaniclastic rocks of the MK domain. 4) A late-stage explosive eruption occurs within the diatreme depositing a thin layer of PVK on top of the MK domain. During this event, several large granitoid blocks fall from the sidewalls and are incorporated into the LC domain. 4) Collapse of crater rims with deposition of well mixed extra-crater material (from earlier eruptions) back into the pipe by mass wasting processes including debris flows and avalanches. 5) Intrusion of the magmatic material of the SC domain along the east side of the pipe through the MK domain into the UC domain, partially along the contact between the diabase dyke and the diatreme. 6) Late-stage alteration of the material within the pipe.

\section{Discussion and Conclusions}

The Pigeon kimberlite is characterized by features that are typical of many of the EKATI kimberlites previously described in Nowicki et al. (2004). The internal geology is simple and includes two main geological domains characterised by contrasting geological textures and diamond grades. The UC domain is comprised of RVK which is thought to have formed by a two stage process. A highly explosive eruption/s initially created the diatreme and during this process, effectively mixed pulverised country rock and juvenile constituents together and ejected them outside the pipe. Following the cessation of explosive activity this material was redeposited into the pipe. The MK domain is comprised of both coherent (magmatic) and volcaniclastic material that includes common broken olivine macrocrysts likely represents a clastogenic type of deposit formed during the waning stages of the eruption within a fully developed, open diatreme.

\section{References}

Kjarsgaard, B.A., 2001. Lac de Gras Kimberlite Field, Slave Province, 1:250,000 geology map and descriptive notes. GSC Open File 3238.

Nowicki, T., Crawford, B., Dyck, D., Carlson, J.A, McElroy, R., Oshust, P.A., Helmstaedt, H., 2004. The geology of kimberlite pipes of the Ekati property, NWT, Canada 